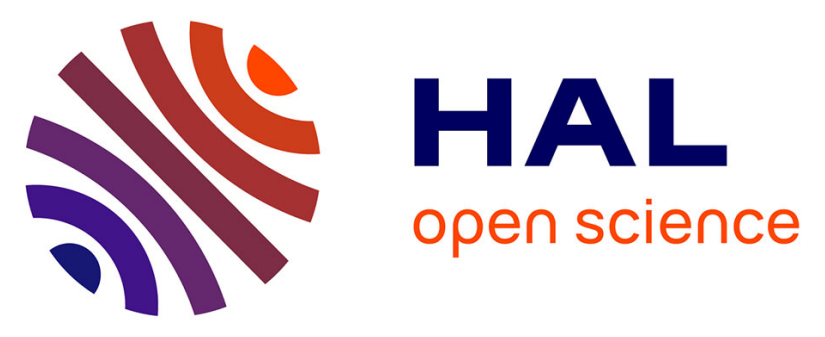

\title{
Uranium isotope geochemistry in modern coastal sediments: Insights from Toulon Bay, France
}

Duc Huy Dang, R. Douglas Evans, Wei Wang, Dario Omanović, Amonda El Houssainy, Véronique Lenoble, Jean-Ulrich Mullot, Stéphane Mounier, Cédric Garnier

\section{To cite this version:}

Duc Huy Dang, R. Douglas Evans, Wei Wang, Dario Omanović, Amonda El Houssainy, et al.. Uranium isotope geochemistry in modern coastal sediments: Insights from Toulon Bay, France. Chemical Geology, 2018, 481, pp.133 - 145. 10.1016/j.chemgeo.2018.01.032 . hal-01879415

\section{HAL Id: hal-01879415 https://hal.science/hal-01879415}

Submitted on 29 Sep 2018

HAL is a multi-disciplinary open access archive for the deposit and dissemination of scientific research documents, whether they are published or not. The documents may come from teaching and research institutions in France or abroad, or from public or private research centers.
L'archive ouverte pluridisciplinaire HAL, est destinée au dépôt et à la diffusion de documents scientifiques de niveau recherche, publiés ou non, émanant des établissements d'enseignement et de recherche français ou étrangers, des laboratoires publics ou privés. 
1

$7 \quad{ }^{1}$ Université de Toulon, PROTEE, EA 3819, CS60584, 83041 Toulon Cedex 9, France

$8 \quad{ }^{2}$ School of the Environment and ${ }^{3}$ Water Quality Centre, Trent University, 1600 West Bank

$10{ }^{4}$ Center for Marine and Environmental Research, Ruđer Bošković Institute, P.O. Box 180,

$12{ }^{5}$ LASEM-Toulon, Base Navale De Toulon, BP 61, 83800 Toulon, France
2

3

4

5 6

9 Drive, Peterborough, ON, Canada K9L 0G2

1110002 Zagreb, Croatia

13

$14 *$ Corresponding author. Tel: +1 7057481011 (ext. 7692).

15 E-mail: huydang@trentu.ca

\section{insights from Toulon Bay, France}

16 


\section{ABSTRACT}

18 By assessing $\mathrm{U}$ geochemistry as well as $\mathrm{U}$ isotopic composition in marine sediments (Toulon Bay, NW Mediterranean Sea), authigenic U accumulation in sediments was found to be tightly linked to that of Mo and V with a slight difference in accumulation rate depending on sediment redox conditions and with a typical U loss in re-oxidized sediments. In sediments collected on a transect along a river plume, the authigenic accumulation of these redoxsensitive elements appears to be linked to the sediment grain size which probably drives the redox status of the sediments. The $\mathrm{U}$ isotopic composition in Toulon Bay sediments showed enrichment of the heavy isotope $\left(\delta^{238} \mathrm{U}=-0.12 \pm 0.12 \%\right.$ relative to CRM-145 in the surface sediments). However, while $U$ isotopic fractionation reaches half fractionation factor $\left(\Delta^{238} U=\right.$ $0.6 \%$ ) in some sediment cores, similar to typical values observed in the literature, other cores show a full fractionation factor $\left(\Delta^{238} \mathrm{U}=1.2 \%\right.$ ). In parallel, the dissolved $U$ profiles do not show a simple and typical depletion trend but rather a depletion in the top $10 \mathrm{~cm}$ followed by release below $10 \mathrm{~cm}$ that is probably linked to the biotic reoxidation of authigenic U(IV). The released $\mathrm{U}$ could be further scavenged by a competition between U-P precipitation and biotic reduction which is most likely driven by diagenetic reactions via porewater acidification and release of chelators and phosphorus.

\section{KEYWORDS}

Uranium; Coastal sediments; Diagenesis; Uranium isotope composition; Multiple regression 


\section{INTRODUCTION}

38 The Anthropocene has been defined as the period when human (i.e., 'anthropogenic') activities have resulted in a significant and global impact on the Earth's climate and ecosystems. These activities have grown exponentially over the last few decades and have led to specific geochemical signatures, distinct from natural and long-term geological processes.

Understanding such processes is essential to discriminate human impacts from the natural geological signature and also to predict future variations. For example, the Earth's oxygenation history is related to geochemical redox processes and so an understanding of these processes is indispensable for comprehending the evolution of life (Lyons et al., 2014). The exchange between the atmosphere and ocean together with seawater-sediment interactions makes marine sediments a valuable archive to evaluate past conditions. The redox sensitive elements (e.g., Mo, U, Re) have been used frequently as proxies of past redox conditions (Holmden et al., 2015; McManus et al., 2006; Siebert et al., 2003). However, further investigations on the control of geochemical processes are required in order to better use such elements as paleo-proxies. Molybdenum and $U$ exhibit conservative behavior in oxygenated water (Chen et al., 1986; Collier, 1985) and exist in the dissolved oxyanion $\left(\mathrm{MoO}_{4}{ }^{2-}\right)$ or oxycation $\left(\mathrm{UO}_{2}{ }^{2+}\right)$ forms, but are reduced and become insoluble in anoxic conditions (Sundby et al., 2004; Yamada et al., 2006; Zheng et al., 2000). This specific character makes their authigenic formation a potential indicator of the redox boundary.

Recent analytical improvements in isotope analyses have enabled the detection and measurement of small variations in $\mathrm{U}$ isotopic compositions. As a result, monitoring the ${ }^{238} \mathrm{U} /{ }^{235} \mathrm{U}$ ratio during $\mathrm{U}$ reduction and authigenic $\mathrm{U}$ formation in sediments has been used to interpret redox variations in the ocean (Andersen et al., 2014; Goto et al., 2014). However, U isotopic fractionation in marine conditions is still not well understood. In addition to reductive 
reactions, other geochemical reactions such as adsorption, (co)precipitation, as well as biogenic $\mathrm{U}$ input could contribute to the variation in isotopic $\mathrm{U}$ composition (Andersen et al., 2014; Brennecka et al., 2011; Dang et al., 2016; Holmden et al., 2015; Stirling et al., 2015, 2007). Even though, $a b$ initio computations and experimental experiments on $U$ biotic reduction have shown that $U$ fractionation could reach a full fractionation factor of $+1.2 \%$ $\left(\Delta^{238} U\right)$ (Abe et al., 2008; Andersen et al., 2014; Bigeleisen, 1996; Dang et al., 2016; Fujii et al., 2006; Stylo et al., 2015), most of natural sedimentary systems record only a U-half fractionation factor $\left(\Delta^{238} \mathrm{U}\right.$ up to $+0.6 \%$, Andersen et al., 2016 and references therein). Recent studies suggest that a U-full fractionation factor could be observed by either a partial U removal from porewater (Andersen et al., 2014) or an early U reduction in the water column which is not transport-diffusion restricted (Andersen et al., 2017). However, this has been only observed in ancient sediments of the Black Sea (Holocene-aged sediments, MontoyaPino et al., 2010; Weyer et al., 2008).

Toulon Bay (NW Mediterranean Sea) provides an interesting study site to assess the impact of human activities during the Anthropocene. The ecosystem was previously found to be highly contaminated by human activities, mainly due to World War II (Dang et al., 2015b; Tessier et al., 2011) when Toulon Bay witnessed several battles. Previous studies on Toulon Bay sediments have revealed that $\mathrm{U}$, as well as $\mathrm{Mo}, \mathrm{Ni}, \mathrm{Co}, \mathrm{V}$ and particulate organic carbon (POC) showed similar behaviors (Dang et al., 2015a). Using Principle Components Analysis (PCA) of 33 chemical parameters measured on 130 surface/deep sediment samples, Dang et al. (2015a) showed that this group of elements was negatively correlated to the group of metal/metalloid contaminants (e.g., $\mathrm{Ag}, \mathrm{Bi}, \mathrm{Cd}, \mathrm{Cu}, \mathrm{Hg}, \mathrm{Pb}, \mathrm{Sn}, \mathrm{Zn}$ ) linked to the historical pollution of Toulon Bay, suggesting either different inputs to the sediments or different diagenetic dynamics in the sediments. However, a better understanding of U geochemistry 
and its isotopic composition in coastal sediments is required for more accurate paleoenvironmental applications.

The purpose of this study was to study $U$ cycling in modern coastal sediments. The study is based on a dataset including (i) U, Mo, V, POC, S, P concentrations in surface sediments (54 stations within Toulon Bay) as well as data from 10 additional stations where 50 -cm sediment cores were taken; (ii) U isotopic composition in 10 sediment cores and 10 surface samples and (iii) spatial and temporal variations in $\mathrm{U}$ and phosphate concentrations in pore waters.

\section{MATERIALS AND METHODS}

\subsection{Study site and sampling}

The samples were collected in Toulon Bay (Fig. 1, NW Mediterranean, SE French coast), which has been impacted by several anthropogenic activities including the Toulon Navy Base (different sites within the harbor), yacht clubs, marinas, small urbanized river inputs and aquaculture. Previous studies on Toulon Bay sediments revealed serious contamination of the entire ecosystem, including the sediments, seawater and biota, e.g. mussels (Dang et al., 2015a; Tessier et al., 2011). The Bay has a water residence time of 1.5 to 7.5 days (Dufresne et al., 2014), low Mediterranean tide and a low input of fresh water (from the Las and Eygoutier Rivers). The Bay also contains a seawall (Fig. 1) that divides it into two unequal parts (a small and a large bay). The sedimentation rate in the Bay was estimated from ${ }^{210} \mathrm{~Pb}$ dating to be $0.21 \pm 0.05 \mathrm{~cm} \mathrm{y}^{-1}$ (Tessier et al., 2011).

With the support of the French Navy (boats, materials, divers), undisturbed surface and subsurface sediments $(0-5$ and 5-10 cm, respectively) were collected from 54 stations situated within the whole of Toulon Bay (Fig. 1) using a sediment corer (10-cm diameter and 1-m long Plexiglas tube) that preserved the sediment water interface (SWI). In addition, sediment cores 
109 ( 50 cm long) were collected at ten specific stations (MIS, 3B, LAS0, LAS1, LAS2, LAS 3,

$11012,15,23$ and 52, Fig. 1) in order to measure parameter depth profiles both spatially (i.e.,

111 along a pollution gradient) and temporally (i.e., seasonally).

112 Stations LAS0, LAS1, LAS2, LAS3 and 23 are situated in front of two main currently active

113 tributaries to the Bay (the Las and Eygoutier Rivers, Fig. 1); the former Las River discharged

114 close to station MIS before it was diverted. Stations MIS, 3B and 12 are located in active

115 military zones with intense ship traffic and station 15 is situated in an aquaculture area (fish

116 and mussel farming). Station 52 is located in the large bay. Samples from stations MIS, 15, 23

117 and 52 were collected in October 2009. Sediments from station 3B and LAS0-1-2-3 were

118 collected in February 2013 and May 2016, respectively. Additionally, 9 other sampling

119 campaigns were carried out at station 12, starting in April 2011 and then every 2 months from

120 May 2012 to July 2013 during which triplicate cores were obtained to determine intra-site

121 variability (Dang et al., 2014a, 2015a). Sediments were sliced every $2 \mathrm{~cm}$ under inert

122 atmosphere $\left(\mathrm{N}_{2}\right)$ and centrifuged (4000 rpm, 15 min, Sigma 3-18K) within $2 \mathrm{~h}$ of collection.

123 Pore waters were collected by filtration of the supernatant water $(0.2-\mathrm{m}$ in-line syringe

124 filters, cellulose acetate, Sartorius) in a $\mathrm{N}_{2}$-purged glove box.

125 In the two tributaries (Las and Eygoutier), particle traps were set up by the IRSN

126 (Radioprotection and Nuclear Safety Institute). Five particle samples were collected during a

127 two-week period from October 2012 to May 2013, mostly during rain events (Dang et al., 128 2015a).

129 All solid fractions were frozen $\left(-18^{\circ} \mathrm{C}\right)$ in HDPE bottles, freeze-dried, 2-mm sieved and then

130 maintained at $-18^{\circ} \mathrm{C}$ until further treatment (semi-total digestion and selective extraction).

131 Further details regarding sediment sampling procedures and sample preparation are detailed

132 elsewhere (Dang et al., 2015a, 2015b, 2014a, 2014b; Tessier et al., 2011). 


\subsection{Sediment and pore water analysis}

134 A digestion was carried out on the freeze-dried sediments using aqua regia/microwave 135 digestion (see Dang et al., 2015a; Tessier et al., 2011 for further details). Total uranium 136 concentrations after digestion $(2 \times 54$ surface/subsurface sediments, i.e., 0-5 and 5-10 cm, 137 respectively and $\sim 250$ core slices $)$ and in porewaters $(\sim 450)$ were determined using HR

138 ICP/MS (Element 2, Thermo Finnigan) at the Ruđer Bošković Institute (RBI, Zagreb,

139 Croatia). Organic carbon concentrations of these sediments and soluble reactive phosphate 140 (SRP) in porewaters have been presented previously (Dang et al., 2014b) and are reported in 141 the present paper to support discussions on $U$ geochemistry.

\section{3. $\mathrm{U}$ stable isotope analysis}

144 For U isotope analysis, sediments were digested and recovery was verified by analysis of 145 MESS-3 certified reference material (National Research Council of Canada). All the acid 146 solutions were double-distilled trace metal analysis grade (BDH Aristar plus; DuoPUR, 147 Milestone). The analytical procedures to determine $\mathrm{U}$ concentration and $\mathrm{U}$ isotope 148 composition were detailed in a previous study (Dang et al., 2016). Briefly, U concentration 149 was analyzed at the Water Quality Centre (WQC) at Trent University (Peterborough, Canada) 150 using an Agilent 8800 ICP/MS (Agilent Technologies, Mississauga, Canada). Chemical 151 separation of $U$ from the matrix was performed using TRU resin (100-150 m, Eichrom). A 152 double spike technique using a mixed ${ }^{233} \mathrm{U} /{ }^{236} \mathrm{U}$ spike (IRMM-3636b) was used for internal 153 correction of instrumental mass fractionation and potential isotope fractionation on the 154 column (Stirling et al., 2007; Weyer et al., 2008). The U isotope measurements were 155 performed by MC-ICP/MS (Nu Plasma II) at the WQC. Samples were introduced using a 156 Cetac Aridus II combined with a PFA nebulizer. The U concentrations were kept at $50 \mathrm{ppb}$ 
157 giving a $\sim 35 \mathrm{~V}$ signal on ${ }^{238} \mathrm{U}$. The contributions of ${ }^{235} \mathrm{U}$ and ${ }^{238} \mathrm{U}$ from the double spike

158 solution are taken into account. The double spike correction was performed using the 159 exponential law. Each sample was bracketed by two double-spiked standard solutions (IRMM

160184 ) and the $U$ concentrations in samples were adjusted to $\pm 10 \%$ of that in the standards.

161 Washout between samples was achieved using a $0.1 \mathrm{M} \mathrm{HCl} / 0.3 \mathrm{M} \mathrm{HF}$ solution. Uranium

162 isotope variation in the sample $\left(\delta^{238} \mathrm{U}\right)$ is reported relative to that of the standard (IRMM163 184), which is defined as:

$$
\delta_{I R M M-184}^{238}=\left[\frac{\left({ }^{238} \mathrm{U} /{ }^{235} \mathrm{U}\right)_{\text {sample }}}{\left({ }^{238} \mathrm{U} /{ }^{235} \mathrm{U}\right)_{\mathrm{IRMM}-184}}-1\right] \times 1000
$$

164 The ${ }^{238} \mathrm{U} /{ }^{235} \mathrm{U}$ ratio in the IRMM 184 was certified to be $137.697 \pm 0.042$ (IRMM, 2015). The $165{ }^{238} \mathrm{U} /{ }^{235} \mathrm{U}$ ratios measured was $137.697 \pm 0.019(2 \mathrm{SD}, \mathrm{n}=75)$ using a $\mathrm{Nu}$ Plasma II with a 166 long-term ${ }^{238} \mathrm{U} /{ }^{235} \mathrm{U}$ ratio of $137.697 \pm 0.042(2 \mathrm{SD}, \mathrm{n}=235)$. In order to compare our data to

167 other studies where CRM-145 was used as standard solution, a $\Delta^{238}$ shift of $-1.102 \%$ is added 168 systematically to the $\delta_{I R M M-184}^{238}$ to convert to $\delta_{C R M-145}^{238}$. Hereafter, the data on U isotopic 169 composition are expressed relative to CRM-145.

\section{RESULTS AND DISCUSSION}

\section{3.1. Uranium distribution in sediments}

172 It is important to discard different phases containing $\mathrm{U}$ which could be detrital $\mathrm{U}$ (lithogenic

$173 \mathrm{U}$ ) and U formed in situ (authigenic U) (Andersen et al., 2014). In Toulon Bay, we assume 174 that the carbonate bound $\mathrm{U}$ is negligible as it has been assumed for the Black Sea sediments 175 (Andersen et al., 2014; Weyer et al., 2008). Therefore, the detrital $U$ ( $\left.\left\{U_{\text {detrital }}\right\}\right)$ is calculated

176 based only on $\mathrm{Al}$ content with a detrital U/Al ratio of $1.8 \times 10^{-5}$ (McManus et al., 2006;

177 Tribovillard et al., 2006): 


$$
\left\{U_{\text {detrital }}\right\}=U / A l_{\text {detrital }} \times\{A l\}
$$

178 The difference between total $U$ and detrital $U$ is assumed to be the authigenic $U\left(\left\{U_{\text {authigenic }}\right\}\right)$.

179 Similar calculations were made for Mo and V using detrital X/Al ratios of $1.1 \times 10^{-5}$ and

$1801.63 \times 10^{-3}$; X being Mo and V, respectively (Kyte et al., 1993; McManus et al., 2006; Morford 181 et al., 2005; Turekian and Wedepohl, 1961).

\subsubsection{Concentrations of total Uranium}

183 The U concentration in the surface sediments of Toulon Bay averaged $2.1 \pm 0.5 \mathrm{~g} \mathrm{~g}^{-1}(\mathrm{n}=54$,

184 Figure 1). The lowest concentrations are observed where the tributaries of the Las and 185 Eygoutier enter Toulon Bay (station LAS0-1-2-3, MIS and 23) and at the open part of the Bay $186\left(1.3 \pm 0.2 \mathrm{~g} \mathrm{~g}^{-1}, \mathrm{n}=9\right)$. This value is close to the $\mathrm{U}$ concentrations measured in particles from 187 the two tributaries (1.0 \pm 0.2 and $2.1 \pm 0.7 \mathrm{~g} \mathrm{~g}^{-1}$ for the Las and Eygoutier, respectively).

188 The total U profiles at ten stations (Figure 2) all show an accumulation trend in the top 10-cm 189 of the core. The uranium accumulation rate (in $\mathrm{g} \mathrm{u} \mathrm{g}^{-1} \mathrm{~cm}^{-1}$ ) computed by integration of $\mathrm{U}$ 190 concentration with depth over the first 10-cm. The values obtained (Table 1) divides the 191 stations into two groups: the first group (stations 3B, 12, 15, 52 and MIS) has a U 192 accumulation averaging $0.21 \pm 0.10 \mathrm{~g} \mathrm{u} \mathrm{g}^{-1} \mathrm{~cm}^{-1}$ while at other stations (LAS0-1-2-3 and 23), 193 only a slight $\mathrm{U}$ accumulation (average of $0.04 \pm 0.05 \mathrm{~g} \mathrm{U} \mathrm{g}^{-1} \mathrm{~cm}^{-1}$ ) was observed. It should be 194 noted that the latter five stations are situated in front of active river mouths (Las and

195 Eygoutier, Figure 1). This increasing in $U$ concentration could be due to either a change in 196 delivered detrital $U$ or in authigenic $U$ accumulation. Moreover, the percentage of the

$197 \mathrm{U}_{\text {authigenic }}$ increases with depth for all ten stations (Figure S1A), starting from different initial 198 values; $58.8 \pm 7.7 \%$ and $83.3 \pm 1.9 \%$ for the two respective groups (Table 1); higher authigenic 199 U percentages are observed for the five stations in front of the river discharge. For the group 200 including stations 3B, 12, 15, 52 and MIS, the percentage of $\mathrm{U}_{\text {authigenic }}$ increases with depth in 
the subsurface sediments (Figure S1A) and a correlation between total and authigenic U 202 accumulation slopes in the top $10 \mathrm{~cm}$ is observed (Fig. S1B). Below $10 \mathrm{~cm}, \mathrm{U}_{\text {authigenic }}$ reaches 203 a maximum (up to 96\%). For stations LAS0-1-2-3, the $\mathrm{U}_{\text {authigenic }}$ fraction was stable at $20487.2 \pm 3.0 \%(n=76)$ throughout the entire core, similar to the $U_{\text {authigenic }}$ fraction observed in 205 the top $15-\mathrm{cm}$ of station $23(82.1 \pm 3.7 \%, \mathrm{n}=8)$.

206 The Ti/Al ratio could indicate either a change in grain size or detrital source (Morford et al., 207 2005). The Ti/Al ratio over the whole Bay surface sediments is constant at $1.4 \pm 0.4 \times 10^{-2}$ $208(\mathrm{n}=54)$, discounting the possibility of a drastic change in detrital source in the Bay and 209 making the Ti/Al ratio a suitable tracer of grain size. The Ti/Al ratios at ten stations are 210 constant throughout the cores (Figure 3A, Table 1) but are particularly higher (2.5 to 3.5 fold) 211 at station LAS0-1-2 (Table 1) compared to the average measured in the 54 surface sediment 212 samples, indicating coarser grain sizes in LAS0, 1, and 2 (Morford et al., 2005). Below $36 \mathrm{~cm}$, 213 the Ti/Al value at station LAS2 decreased to the average seen in the Bay together with a 214 significant accumulation of $\mathrm{U}$ (Figure 3B). The pollution (e.g., $\mathrm{Hg}, \mathrm{Ag}, \mathrm{Bi}$ and other metals) 215 peak attributed to the World War II events (Dang et al., 2015a; Tessier et al., 2011), is deeper 216 at station LAS 2 compared to the rest of the Bay (starting at $-39 \mathrm{~cm}$ instead of $-15 \mathrm{~cm}$ ), which 217 suggests a higher sedimentation rate at this station. The change in Ti/Al profile at station 218 LAS2 (Figure 3B) could correspond to a change in the hydrological regime of the Las River 219 which may have previously carried different types of particles. This could be attributed to the 220 reinforced concrete structure that was built to definitively divert the former Las River to the 221 current river in the 1870s (Région Provence Alpes Côte d'Azur, 2008) and/or the Dardennes 222 dam built on the upstream of the Las River in 1912 (Laliche et al., 2015). A disruption in the nature of delivered particles would also alter the porosity of the sediments and induce a change in $\mathrm{U}$ accumulation (Figure 3B). 
At the scale of the whole bay, authigenic U, Mo, V concentrations are inversely proportional to the $\mathrm{Ti} / \mathrm{Al}$ ratios; this trend is more apparent at four stations in front of the Las River (Figure 4). This suggests that coarser sediments are not favorable for the accumulation of these redox sensitive elements, probably because of enhanced diffusion of oxidizing species from seawater which delay diagenetic activities (refer to the SRP profiles which will be further 230 discussed).

231 In summary, the stations situated in front of the currently active rivers (LAS0-1-2-3 and 23) are different from the other stations; $\mathrm{U}$ accumulation is lower at the former stations (low total concentration and higher contribution of detrital $\mathrm{U}$ ) and begins closer to the sediment water interface (i.e., in the first $\mathrm{cm}$ ) than at the latter stations. This could be due to differences in the input of terrestrial materials (e.g., organic matter) or a change in porosity enhancing diffusion and oxygen penetration (McManus et al., 2005).

In deep sediments (below $15 \mathrm{~cm}$ ), the almost constant contribution of $\mathrm{U}_{\text {authigenic }}$ (Figure $\mathrm{S} 1 \mathrm{~A}$ )

238 shows that authigenic $U$ is preserved in sediments, except for stations 3 and MIS. In fact, 239 previous studies have demonstrated that the sediments at stations 12, 3B and MIS have been 240 totally (the whole MIS core) or partially mixed (from -15 to $-35 \mathrm{~cm}$ at station $3 \mathrm{~B}$ and some 241 specific depths at station 12) during World War II events (Dang et al., 2015a, 2015b). These 242 depths correspond to a loss of authigenic U (Figure S1A) probably due to oxidation during 243 mixing events (Algeo and Maynard, 2004; Tribovillard et al., 2006). Total U profiles do not 244 show further accumulation at depth for stations 3B, 52, MIS, LAS1 and until $-35 \mathrm{~cm}$ for 245 LAS2 (Figure 2). However, significant U accumulation is observed for stations 12, 15, 23 and 246 the bottom of the LAS2 core. The redox status of the sediments and post-depositional 247 reoxygenation would impact $U$ geochemistry leading to the different $U$ profiles observed in 248 these sediment cores. This will be further discussed in the following sections. 
The authigenic U concentrations are significantly correlated to that of Mo and V (Figure S2)

250 because of their similar behavior, which is typical of redox-sensitive elements (Morford et al., 251 2009; Sundby et al., 2004; Tribovillard et al., 2006). However, they differ in their 252 geochemistry leading to various accumulation rates depending on the redox status of the 253 depositional environment (Algeo and Maynard, 2004; Tribovillard et al., 2006). In fact, U 254 reduction leading to $\mathrm{U}$ accumulation involves soluble $\mathrm{U}\left(\mathrm{VI}\right.$ : mainly $\left.\mathrm{UO}_{2}\left(\mathrm{CO}_{3}\right)_{3}{ }^{4-}\right)$ and 255 insoluble U(IV). This reduction could happen under denitrifying conditions (anoxia) (Algeo and Maynard, 2004; McManus et al., 2005). However, the key step leading to Mo accumulation within sediments is the sulfide activation of conservative molybdate ions to reactive thio-species (Helz et al., 1996). This step is related to sulfate-reduction and then favored in sulfidic conditions (Adelson et al., 2001). Vanadium accumulation in the sediments 260 results from two reduction steps $(\mathrm{V}(\mathrm{V}) \rightarrow \mathrm{V}(\mathrm{IV}) \rightarrow \mathrm{V}(\mathrm{III}))$. The first step begins in non-sulfidic anoxic environments while the latter is fostered by free sulfide (in euxinic conditions)

262 (Tribovillard et al., 2006 and references therein).

263 Consequently, the U, Mo and V accumulate differently in the ten sediments cores when 264 compared using linear regression (Figure S2). A multiple regression model highlights the 265 relationship between the three elements (Table S1). Further details on the data treatment 266 process and its validation are shown in the Supplementary Information.

267 Four groups are revealed corresponding to four relationship equations (Figures 5, S3 and 268 Table S1). At stations 3B and MIS, a flat plane shows that authigenic U accumulation is the 269 least important when compared to that of Mo and V concentrations (low slopes of 0.03 and 270 0.01, for $\{\mathrm{U}\}$ vs Mo and V, respectively, Table S1, Figures 5 and S3). This confirms the 271 hypothesis of $U$ loss by post-depositional reoxygenation (Algeo and Maynard, 2004; 272 Tribovillard et al., 2006) previously discussed. In the sediments at stations LAS0-1-2-3, 12, 
273

52 and all surface sediments, the relationship between authigenic $U$ and Mo was stronger than that of $\mathrm{V}$ (slope of 0.27 and 0.05 , respectively, Table S1). In fact, authigenic V, unlike authigenic $\mathrm{U}$ and Mo, is only weakly enriched in these sediments when compared to the other five stations (Figure S2). The authigenic U-Mo relationships are similar at stations 23 and 15 (slope of 0.45 and 0.48 , respectively) while the $\mathrm{U}-\mathrm{V}$ relationships are significantly different (slope of 0.06 and 0.24 , respectively, Figure 4, Table S1). In addition, the accumulation zone of total $\mathrm{S}$ extends from the surface down to $15 \mathrm{~cm}$ for station 15 and to $30 \mathrm{~cm}$ for station 23 , corresponding to a longer anoxic-to-euxinic transition at station 23 than at 15 (Figure S4). As the anoxic condition is more favorable for $\mathrm{U}$ and $\mathrm{V}$ accumulation than for Mo which is accumulated in euxinic conditions only (see discussion above), the comparison among $\mathrm{U}_{\text {authigenic }}, \mathrm{Mo}_{\text {authigenic }}, \mathrm{V}_{\text {authigenic }}$ confirms the anoxic status at station 23 and euxinic conditions at station 15. The S content in Toulon Bay (Figure S5) shows significantly higher values along the coast (up to $1.9 \%$ ) than the open sea $(0.38 \pm 0.06 \%, \mathrm{n}=10)$. The $\mathrm{S}$ accumulation with sediment depth increases equally from the coast to the open sea (Figure S4), potentially indicating a redox gradient.

To summarize, the preserved sediments could be classified on an euxinic-to-anoxic gradient: 15-23-52-LAS0-1-2-3. In addition, three other stations have been subjected to postdepositional reoxygenation events, from minor to total mixing $(12<3 \mathrm{~B}<\mathrm{MIS})$ having a direct impact on the redox status of the sediments.

\subsubsection{Uranium isotopic composition}

The $\delta^{238} \mathrm{U}$ values in the top surface sediments averaged $-0.12 \pm 0.12 \%$ (relative to CRM-145, $\mathrm{n}=25)$, close to the estimated $\mathrm{U}$ isotopic composition in hypoxic sediments $(-0.24 \pm 0.08 \%$, (Andersen et al., 2016)). When compared to the value of $\delta^{238} U_{\text {seawater }}(-0.39 \pm 0.02 \%$, (Noordmann et al., 2015; Romaniello et al., 2013; Tissot and Dauphas, 2015; Weyer et al., 
2008), $U$ accumulation in surface sediments would lead to an enrichment of $\Delta^{238} U_{\text {seawater- }}$ sediments of $0.27 \pm 0.14 \%$, similar to that observed in the oceanic crust $(0.25 \%$ (Andersen et al., 2016)) and carbonate sediments (0.2-0.4\%o (Romaniello et al., 2013)).

In eight stations where $U$ isotope profiles were measured, the $\delta^{238} U$ profiles once again divide themselves into 2 groups, the first group being stations 3B, 12, 15 and 52. Station 3B showed an increasing $\delta^{238} \mathrm{U}$ from a value close to that of the seawater, i.e., $-0.37 \%$ in the surface sediments to $+0.07 \%$ at the bottom of the core while stations 12,15 and 52 displayed almost constant $\delta^{238} U$ profiles throughout the cores $\left(\delta^{238} U=-0.19 \pm 0.06,-0.07 \pm 0.08\right.$ and $-0.07 \pm 0.04$ $\%$, respectively) (Figure 5). These values are comparable to the profile reported for US West Coast hypoxic margin sediment (Andersen et al., 2016). The second group, involving all stations situated close to the river mouths, has a continuously increasing $\delta^{238} \mathrm{U}$ signature with an average of $-0.05 \pm 0.07 \%$ in the surface sediments up to $0.74 \%$ at $40-50 \mathrm{~cm}$ in the core (Figure 6).

Andersen et al. (2016) have gathered published literature on $U$ isotopic composition and $U$ accumulation in sediments and categorized them into two main groups: "hypoxic type" and "euxinic type" regarding the redox state of the water column. We have taken the Peru margin sediments reported by Andersen et al. and placed them into another plot (Figure S6) as they are organic-rich and seem to be strongly influenced by continental inputs-more so than two other types (Andersen et al., 2016; Weyer et al., 2008). Comparing our data to these three types of conditions (Figure 7A), and factoring in the oxic conditions in the water column of Toulon Bay most of sediments would be categorized as "hypoxic" thus extending the range of isotopic composition up to $0.8 \%$. 
Using the isotopic mass balance, the $\mathrm{U}$ isotopic composition in the authigenic fraction is 320 calculated, assuming a detrital U composition of $-0.3 \%$ (Andersen et al., 2014), which is 321 close to the $U$ isotopic composition of the Garonne and Rhone rivers $(-0.32 \pm 0.04 \%$ and $3220.26 \pm 0.06 \%$, respectively (Andersen et al., 2016; Tissot and Dauphas, 2015)).

$$
\delta^{238} U_{\text {authigenic }}=\frac{\delta^{238} U_{\text {bulk }}-\delta^{238} U_{\text {detrital }} \times f_{\text {detrital }}}{f_{\text {authigenic }}}
$$

323 With $\delta^{238} \mathrm{U}_{\text {bulk }}, \delta^{238} \mathrm{U}_{\text {detrital }}$ and $\delta^{238} \mathrm{U}_{\text {authigenic }}$ being the $\mathrm{U}$ isotopic composition of total, detrital 324 and authigenic $U$ and $f_{\text {detrital }}$ and $\mathrm{f}_{\text {authigenic }}$ being the $\mathrm{U}$ distribution in these two fractions.

325 The $\delta^{238} U_{\text {authigenic }}$ is plotted against the $U_{\text {authigenic }}$ and compared to that in the bulk fraction 326 (Figure 7B). Three scenarios are apparent from the three lines in Figures 7B, all starting from 327 the $\mathrm{U}$ isotopic composition of seawater (-0.39\%). All the surface sediments, station MIS, 328 LAS1, top layer of LAS2, and 52 are not highly enriched in $\mathrm{U}$ (up to $3 \mathrm{~g} \mathrm{~g}^{-1}$ only) but $\mathrm{U}$ 329 isotopes are highly fractionated. Stations 3B, 23 and the bottom layers of LAS2 display both $330 \mathrm{U}$ accumulation and isotope fractionation. Sediments from stations 12 and 15 are only slightly 331 enriched in the heavy isotope but highly enriched in U. These two stations seem to be closer 332 to what has been observed in the literature with the continental conditions seen in the Peru 333 margin sediments (Andersen et al., 2016; Weyer et al., 2008). Furthermore, it should be noted 334 that the $\delta^{238} \mathrm{U}$ values observed in Toulon Bay, mostly in stations MIS, LAS2 and 23 are the 335 highest recorded in the literature in natural sediments. That said, these values are still within 336 the theoretical range of the full $\mathrm{U}$ fractionation factor $(+1.2 \%$ ) (Abe et al., 2008; Andersen et 337 al., 2014; Fujii et al., 2006). Andersen et al. (2014) proposed four scenarios for how 338 depositional environments would impact on $U$ and $U$ isotope accumulation in sediments. The 339 half $\mathrm{U}$ fractionation factor seems to be the consensual values recorded in marine sediments 340 worldwide (Andersen et al., 2014; Goldmann et al., 2015; Holmden et al., 2015; Montoya- 
341 Pino et al., 2010; Noordmann et al., 2015; Tissot and Dauphas, 2015; Weyer et al., 2008).

342 Most of Toulon Bay sediments fall into the "oxic penetration zone" scenario defined by 343 Andersen et al. (2014) with half fractionation factor corresponding to a value of $0.2 \%$

344 (Figure 7B). In addition, a possible scenario leading to such high $\mathrm{U}$ isotope composition (0.2$3450.8 \%$, Andersen et al., 2014) is when U is accumulated in sediments without a full extraction 346 of $U$ from porewater (i.e., partial U removal). A more recent hypothesis suggests that the early $347 \mathrm{U}$ reduction in the floc layer above the sediments that is not transport-diffusion restricted 348 would express full isotope fractionation (Andersen et al., 2017). Both these hypotheses 349 correspond to the conditions observed at stations LAS1, LAS2, MIS and 23 (Figure 7B) 350 where sediments are submitted to a direct delivery of terrestrial materials, probably consisting 351 of coarse particles, which leads to a stronger diffusion compared to a well consolidated 352 sediment pile. Also, these sediments are either post-depositionally reoxygenated (MIS) or 353 suboxic/anoxic sediments (LAS2 and 23, see discussion above). These characteristics would 354 lead to a full fractionation factor.

\subsection{Uranium in pore water}

356 The concentration profiles of $U$ and SRP in pore waters at stations 3B, 12, 15, 52, LAS2-3 357 and 23 are shown in Figures 8 and S7. The SRP results have been previously discussed (Dang 358 et al., 2015a, 2014a, 2014b) and are shown here to support the discussion on the diagenetic 359 behavior of $\mathrm{U}$.

360 For all seven U profiles, typical U profiles in porewater (constant concentration or depletion 361 from porewater) (Barnes and Cochran, 1993; McManus et al., 2006; Morford et al., 2005; 362 Tribovillard et al., 2006) are observed only in the first $10 \mathrm{~cm}$ (Figure 8) where authigenic U 363 formation is effective (see discussion above). Below that depth, $U$ is strongly released in 364 porewater. The high $U$ concentration in the surface sediment porewater was attributed to 
oxygen penetration (McManus et al., 2005); U release in deep sediments has not been

366 attributed to geochemical processes but rather to either re-oxygenation of the sediment during handling or sediment oxidation by (bio)irrigation (Chaillou et al., 2002; Morford et al., 2009). However, in Toulon Bay, the absence of macrofauna and plant/algae (Bernard et al., 2001) discounts the contribution of bioirrigation and bioturbation (Dang et al., 2014b). Also, the continuously increasing sulfide profiles with depth in these cores (Dang et al., 2015a, 2014b) together with the apparent release of $U$ in the middle of the sediment cores (Figures 8, S7) exclude the hypothesis of oxygen penetration from the bottom during coring operations. Therefore, the $\mathrm{U}$ release in deep anoxic/euxinic sediments is not a simple artefact but results

374 from a specific suite of biogeochemical processes. For example, biotic oxidation of authigenic 375 U(IV) has been shown to solubilize U (Beller, 2005; Stewart et al., 2012; Weber et al., 2011), 376 possibly from previous $\mathrm{U}$ accumulation in sediments due to the reduction to $\mathrm{U}(\mathrm{IV})$ minerals 377 (Algeo and Maynard, 2004; McManus et al., 2005). Also, studies have demonstrated that the 378 first $10 \mathrm{~cm}$ of the sediments core were controlled by $\mathrm{Mn} / \mathrm{Fe}$ cycling but diagenetic products $379\left(\mathrm{NH}_{4}{ }^{+}, \mathrm{SRP}, \mathrm{DIC}, \mathrm{Si}(\mathrm{OH})_{4}\right)$ were strongly released below $15 \mathrm{~cm}$, indicating a highly reactive 380 layer (Dang et al., 2014a, 2014b). This intense diagenesis may enhance the oxidation of 381 biogenic U(IV) either because of deviation in $\mathrm{pH}$ from neutral (Ginder-Vogel et al., 2010) or 382 because of an increase in U solubility by the release of potential chelators (e.g., organic matter 383 or carbonate) (Ginder-Vogel et al., 2010; Stewart et al., 2012). The observed increase in 384 soluble $\mathrm{U}$ is supported by the significant relationship between dissolved $\mathrm{U}$ and sediment $\mathrm{U}$ 385 (Figure 9) and highlights the redistribution between the dissolved and particulate fraction of 386 uranium.

387 The interaction between SRP and dissolved U may also influence the redistribution of U 388 between dissolved and particulate phases. The release of dissolved $U$ in the presence of SRP 
produces a precipitate and leads to a reduction in SRP. Thus an inverse relationship would be 390 expected between SRP and dissolved uranium. In fact, at stations 15 and 23, where SRP 391 levels are low throughout the cores dissolved U concentrations are high (up to 200-300 M $392 \mathrm{U})$ and at stations 3 and 12, SRP concentrations are inversely proportional to U, even though 393 the profiles of both elements vary within the core (Figures 8 and S7). This phenomenon as 394 well seems to be affected by seasonal variations as observed at station 12 (Figure S7): the 395 dissolved $U$ peak at $-25 \mathrm{~cm}$ decreases in intensity with time and with increasing SRP. At 396 stations LAS2 and LAS3, the SRP profiles support the previous hypothesis on the diagenesis delay due to enhanced diffusion of oxidizing species from seawater. In fact, SRP (and $\mathrm{Si}(\mathrm{OH})_{4}$, data not shown) was strongly produced below $20 \mathrm{~cm}$ at station LAS2 while a release 399 of these species was encountered from the SWI at station LAS3.

400 The $\mathrm{pH}$ profiles at six stations (3B, 12, 15, 23 and LAS2-3) highlight a clear difference 401 between 3B-12-LAS2-3 and 15-23 (Figure S8). The porewaters below the sediment/water 402 interface consistently show a lower $\mathrm{pH}$ value than that of the seawater (8.1-8.2). For stations 403 3B and 12, this value remains stable for the first $20 \mathrm{~cm}$ then markedly decreases down to 6.5 404 below $20 \mathrm{~cm}$. Alternately, the porewater $\mathrm{pH}$ at stations 15 and 23 is constant at a value of $4057.7 \pm 0.1(n=48)$ throughout the whole core. A similar trend was observed for the redistribution 406 between protein-like and humic like fluorophores at these stations (Dang et al., 2014a, 407 2014b); dominance of protein-like organic matter in the top $20 \mathrm{~cm}$ is followed by a switch to 408 humic-like organic matter below $20 \mathrm{~cm}$ at station 12, while at station 15 (sediment core 409 collected on November 2009) a dominance of protein-like organic matter occurs throughout 410 the whole core. These observations confirm strong diagenetic reactions below $20 \mathrm{~cm}$ at 411 stations $3 \mathrm{~B}$ and 12 , while a constant and weaker reactivity was observed at stations 15 and 23 412 (Dang et al., 2014a, b). 
413 The U-P precipitation system in a seawater matrix at different $\mathrm{pH}$ values was modeled with 414 PHREEQC (version 2.18.3,40) similar to an approach previously described (Dang et al., 415 2016). Briefly, the chemical speciation and the mineral saturation index in mixtures consisting 416 of $\mathrm{U}$ and $\mathrm{P}$ (in the concentration range of our samples: 1 to $500 \mathrm{nM}$ and $1 \mu \mathrm{M}$ to $100 \mathrm{M}$, 417 respectively) in the seawater matrix was calculated (Figure S9) for a range of $\mathrm{pH}$ values (6-8) 418 that are relevant when considering the observed variations in the porewaters. Negative values 419 suggest that the formation of the concerned mineral is not thermodynamically favored while 420 increasing values to zero show higher potential for mineral precipitation. At the concentration 421 range found in Toulon Bay sediments, the formation of Na-autunite is more favored with a 422 decreasing $\mathrm{pH}$ (Figure S9); concretely speaking, U-P precipitation is more probable at stations $4233 \mathrm{~B}$ and 12 than at stations 15 and 23.

424 In summary, the situations in which high $U$ release is observed (stations 15 and 23) 425 correspond to a low-to-intermediate diagenetic reactivity (i.e., lower $\mathrm{pH}$, less SRP 426 production). Therefore, $\mathrm{U}$ removal relies only on $\mathrm{U}$ reduction, the intensity of which may be 427 different depending on the redox status of the sediments and on bacterial activities. Previous 428 work has demonstrated that the dissolved organic matter at station 15 is dominated by protein429 like fluorophores, potentially related to the location of this station near an aquaculture area 430 (Dang et al., 2014b). In the reverse case, when diagenetic activities are more intense, 431 porewater tends to be SRP-richer and decreases in $\mathrm{pH}$, conditions for which the precipitation 432 of U-P mineral competes with U biotic reduction. Moreover, U-P precipitation does not 433 induce $\mathrm{U}$ isotopic fractionation while $\mathrm{U}$ biotic reduction does with a full fractionation factor 434 of $1.2 \%$ (Andersen et al., 2016; Dang et al., 2016; Stylo et al., 2015). This competition 435 between biotic reduction of $\mathrm{U}$ and biomineralization of U-P minerals has already been 436 observed in a previous study (Salome et al., 2013). 


\section{CONCLUSIONS}

439 The dataset obtained on $\mathrm{U}$ isotope geochemistry permits a better understanding of $\mathrm{U}$ cycling

440 in modern coastal sediments. The impact of terrestrial particle size has been demonstrated to 441 be directly driving the accumulation of $\mathrm{U}$, Mo and V via the redox status of the sediments. 442 Also, the impact of human activities on sediment integrity induces variations in elemental 443 geochemistry that differ from other systems where $U$ isotopic compositions have been 444 recorded (Andersen et al., 2016 and references therein). This study has reported a full U 445 fractionation factor in modern sediments which has been previously reported only in 446 Holocene-aged sediments of the Black Sea. These data support that enhanced diffusion in 447 coarser sediments could supply a larger $U$ amount than in a compact sediment pile and that 448 could lead to a more effective $U$ isotope fractionation. In addition, this study reports an 449 anaerobic oxidation of authigenic U(IV) which leads to a strong release of dissolved U in 450 deep porewater. The trapping effect of SRP on the released U is attributed to strong diagenetic 451 activities leading to increasing insolubility of U-P minerals. Also, as U precipitation in 452 phosphate mineral does not induce isotopic fractionation, we suggest that the contribution of 453 SRP may alter the full $U$ fractionation factor and SRP release is driven by the redox status of 454 the sediments (indirectly linked to diagenesis and sediment characteristics). However, further 455 studies are required to further test these hypotheses as the atypical dissolved U profiles and 456 high $\mathrm{U}$ isotopic composition have not been observed previously in the literature.

\section{ACKNOWLEDGEMENTS:}

459 This study was part of the MerMex-WP3-C3A/MISTRALS research program (part of the 460 international IMBER, LOICZ and SOLAS projects), and funded through the CARTOCHIM, 
CARTOC, PREVENT and METFLUX research programs (funded by "Toulon-ProvenceMéditerranée (TPM)", the "Région PACA", and "l'Agence de l'Eau Rhône-Méditerranée et Corse"). DHD's Ph.D. and postdoctoral fellowship were respectively supported by the French Ministry of National Education, Higher Education and Research and a Canadian NSERC (Natural Sciences and Engineering Research Council) Collaborative Research and Development Grant to RDE, which also funded the analyses carried out at the Trent WQC. The authors wish to thank the French Navy for diving and sampling assistance, Dr. Bastian Georg for assistance with isotope measurements and Dr. Hayla Evans for English correction and manuscript revision.

\section{REFERENCES}

Abe, M., Suzuki, T., Fujii, Y., Hada, M., Hirao, K., 2008. Ligand effect on uranium isotope fractionations caused by nuclear volume effects: An ab initio relativistic molecular orbital study. J. Chem. Phys. 129, 164309. doi:10.1063/1.3463797

Adelson, J.M., Helz, G.R., Miller, C. V., 2001. Reconstructing the rise of recent coastal anoxia; molybdenum in Chesapeake Bay sediments. Geochim. Cosmochim. Acta 65, 237-252. doi:10.1016/S0016-7037(00)00539-1

Algeo, T.J., Maynard, J.B., 2004. Trace-element behavior and redox facies in core shales of Upper Pennsylvanian Kansas-type cyclothems. Chem. Geol. 206, 289-318. doi:10.1016/j.chemgeo.2003.12.009

Andersen, M.B., Romaniello, S., Vance, D., Little, S.H., Herdman, R., Lyons, T.W., 2014. A modern framework for the interpretation of $238 \mathrm{U} / 235 \mathrm{U}$ in studies of ancient ocean redox. Earth Planet. Sci. Lett. 400, 184-194. doi:10.1016/j.epsl.2014.05.051

Andersen, M.B., Stirling, C.H., Weyer, S., 2017. Uranium Isotope Fractionation, in: Teng, F.Z., Watkins, J., Dauphas, N. (Eds.), Reviews in Mineralogy \& Geochemistry. pp. 799850.

Andersen, M.B., Vance, D., Morford, J.L., Bura-Nakić, E., Breitenbach, S.F.M., Och, L., 
2016. Closing in on the marine 238U/235U budget. Chem. Geol. 420, 11-22. doi:10.1016/j.chemgeo.2015.10.041

Barnes, C.E., Cochran, J.K., 1993. Uranium geochemistry in estuarine sediments: Controls on removal and release processes. Geochim. Cosmochim. Acta 57, 555-569. doi:10.1016/0016-7037(93)90367-6

Beller, H.R., 2005. Anaerobic, nitrate-dependent oxidation of U (IV) oxide minerals by the chemolithoautotrophic Bacterium Thiobacillus denitrificans. Appl. Environ. Microbiol. 2170-2174. doi:10.1128/AEM.71.4.2170

Bernard, G., Denis, J., Deneux, F., Belsher, T., Sauzade, D., Boudouresque, C.F., Charbonnel, E., Emery, E., Herve, G., Bonhomme, P., 2001. Etude et cartographie des biocénoses de la rade de Toulon, in: Contrat D'étude Pour Le Syndicat Intercommunal de l'Aire Toulonaise, Ifremer et GISPosidonie. Ifremer Publ, La Seyne, p. 150.

Bigeleisen, J., 1996. Nuclear size and shape effects in chemical reactions. Isotope chemistry of the heavy elements. J. Am. Chem. Soc. 118, 3676-3680. doi:10.1021/ja954076k

Brennecka, G., Wasylenki, L.E., Weyer, S., Anbar, a D., 2011. Uranium isotope fractionation during adsorption to manganese oxides. Environ. Sciene Technol. 1370-1375.

Chaillou, G., Anschutz, P., Lavaux, G., Schäfer, J., Blanc, G., 2002. The distribution of Mo, $\mathrm{U}$, and $\mathrm{Cd}$ in relation to major redox species in muddy sediments of the Bay of Biscay. Mar. Chem. 80, 41-59. doi:10.1016/S0304-4203(02)00097-X

Chen, J.H., Lawrence Edwards, R., Wasserburg, G.J., 1986. 238U,234U and232Th in seawater. Earth Planet. Sci. Lett. 80, 241-251. doi:10.1016/0012-821X(86)90108-1

Collier, R.W., 1985. Molybdenum in the Northeast Pacific Ocean. Limnol. Oceanogr. 30, 1351-1354. doi:10.4319/lo.1985.30.6.1351

Dang, D.H., Breda, N., Wang, W., Georg, R.B., Evans, D., 2016. Uranium isotope fractionation during adsorption, (co)precipitation and biotic reduction. Environ. Sci. Technol. 50, 12695-12704.

Dang, D.H., Lenoble, V., Durrieu, G., Mullot, J.-U., Mounier, S., Garnier, C., 2014a. Sedimentary dynamics of coastal organic matter: An assessment of the porewater size/reactivity model by spectroscopic techniques. Estuar. Coast. Shelf Sci. 151, 100- 
Dang, D.H., Lenoble, V., Durrieu, G., Omanović, D., Mullot, J.-U., Mounier, S., Garnier, C., 2015a. Seasonal variations of coastal sedimentary trace metals cycling: Insight on the effect of manganese and iron (oxy)hydroxides, sulphide and organic matter. Mar. Pollut. Bull. 92, 113-124. doi:10.1016/j.marpolbul.2014.12.048

Dang, D.H., Schaefer, J., Brach-Papa, C., Lenoble, V., Durrieu, G., Dutruch, L., Chiffoleau, J.-F., Gonzalez, J.-L., Blanc, G., Mullot, J.U., Mounier, S., Garnier, C., 2015 b. Evidencing the impact of coastal contaminated sediments on mussels through $\mathrm{Pb}$ stable isotopes composition. Environ. Sci. Technol. 49, 11438-11448. doi:10.1021/acs.est.5b01893

Dang, D.H., Tessier, E., Lenoble, V., Durrieu, G., Omanović, D., Mullot, J.-U., Pfeifer, H.-R., Mounier, S., Garnier, C., 2014b. Key parameters controlling arsenic dynamics in coastal sediments: an analytical and modeling approach. Mar. Chem. 161, 34-46.

Dufresne, C., Duffa, C., Rey, V., 2014. Wind-forced circulation model and water exchanges through the channel in the Bay of Toulon. Ocean Dyn. 64, 209-224. doi:10.1007/s10236-013-0676-3

Fujii, Y., Higuchi, N., Haruno, Y., Nomura, M., Suzuki, T., 2006. Temperature dependence of isotope effects in uranium chemical exchange reactions. J. Nucl. Sci. Technol. 43, 400406. doi:10.1080/18811248.2006.9711111

Ginder-Vogel, M., Stewart, B., Fendorf, S., 2010. Kinetic and mechanistic constraints on the oxidation of biogenic uraninite by ferrihydrite. Environ. Sci. Technol. 44, 163-169. doi:10.1021/es $902452 \mathrm{u}$

Goldmann, A., Brennecka, G., Noordmann, J., Weyer, S., Wadhwa, M., 2015. The uranium isotopic composition of the Earth and the Solar System. Geochim. Cosmochim. Acta 148, 145-158. doi:10.1016/j.gca.2014.09.008

Goto, K.T., Anbar, A.D., Gordon, G.W., Romaniello, S.J., Shimoda, G., Takaya, Y., Tokumaru, A., Nozaki, T., Suzuki, K., Machida, S., Hanyu, T., Usui, A., 2014. Uranium isotope systematics of ferromanganese crusts in the Pacific Ocean: Implications for the marine 238U/235U isotope system. Geochim. Cosmochim. Acta 146, 43-58. 
Helz, G.R., Miller, C. V., Charnock, J.M., Mosselmans, J.F.W., Pattrick, R. a D., Garner, C.D., Vaughan, D.J., 1996. Mechanism of molybdenum removal from the sea and its concentration in black shales: EXAFS evidence. Geochim. Cosmochim. Acta 60, 36313642. doi:10.1016/0016-7037(96)00195-0

Holmden, C., Amini, M., Francois, R., 2015. Uranium isotope fractionation in Saanich Inlet: A modern analog study of a paleoredox tracer. Geochim. Cosmochim. Acta 153, 202215. doi:10.1016/j.gca.2014.11.012

IRMM, 2015. Nuclear certified reference materials, Institute for Reference Materials and Measurements (IRMM). Geel, Belgium.

Kyte, F.T., Leinen, M., Ross Heath, G., Zhou, L., 1993. Cenozoic sedimentation history of the central North Pacific: Inferences from the elemental geochemistry of core LL44-GPC3. Geochim. Cosmochim. Acta 57, 1719-1740. doi:10.1016/0016-7037(93)90109-A

Laliche, K., Venier, R., Degoutte, G., Meriaux, P., Patouillet, B., Bailleul, J., Laliche, K., Venier, R., Degoutte, G., Meriaux, P., Patouillet, B., 2015. Dardennes dam: foundation investigations and diagnosis before reinforcement studies, in: Colloque CFBR " Fondations Des Barrages : Caracterisation, Traitements, Surveillance, Rehabilitation ”.

Lyons, T.W., Reinhard, C.T., Planavsky, N.J., 2014. The rise of oxygen in Earth's early ocean and atmosphere. Nature 506, 307-15. doi:10.1038/nature13068

McManus, J., Berelson, W.M., Klinkhammer, G.P., Hammond, D.E., Holm, C., 2005. Authigenic uranium: Relationship to oxygen penetration depth and organic carbon rain. Geochim. Cosmochim. Acta 69, 95-108. doi:10.1016/j.gca.2004.06.023

McManus, J., Berelson, W.M., Severmann, S., Poulson, R.L., Hammond, D.E., Klinkhammer, G.P., Holm, C., 2006. Molybdenum and uranium geochemistry in continental margin sediments: Paleoproxy potential. Geochim. Cosmochim. Acta 70, 4643-4662. doi:10.1016/j.gca.2006.06.1564

Montoya-Pino, C., Weyer, S., Anbar, A.D., Pross, J., Oschmann, W., van de Schootbrugge, B., Arz, H.W., 2010. Global enhancement of ocean anoxia during oceanic anoxic event 2: A quantitative approach using $U$ isotopes. Geology 38, 315-318. 
Morford, J.L., Emerson, S.R., Breckel, E.J., Kim, S.H., 2005. Diagenesis of oxyanions (V, U, $\mathrm{Re}$, and $\mathrm{Mo}$ ) in pore waters and sediments from a continental margin. Geochim. Cosmochim. Acta 69, 5021-5032. doi:10.1016/j.gca.2005.05.015

Morford, J.L., Martin, W.R., François, R., Carney, C.M., 2009. A model for uranium, rhenium, and molybdenum diagenesis in marine sediments based on results from coastal locations. Geochim. Cosmochim. Acta 73, 2938-2960. doi:10.1016/j.gca.2009.02.029

Noordmann, J., Weyer, S., Montoya-Pino, C., Dellwig, O., Neubert, N., Eckert, S., Paetzel, M., Böttcher, M.E., 2015. Uranium and molybdenum isotope systematics in modern euxinic basins: Case studies from the central Baltic Sea and the Kyllaren fjord (Norway). Chem. Geol. 396, 182-195. doi:10.1016/j.chemgeo.2014.12.012

Région Provence Alpes Côte d'Azur, 2008. Le Las: Une Rivière dans la Ville. Val d'As, Toulon.

Romaniello, S.J., Herrmann, A.D., Anbar, A.D., 2013. Uranium concentrations and 238U/235U isotope ratios in modern carbonates from the Bahamas: Assessing a novel paleoredox proxy. Chem. Geol. 362, 305-316. doi:10.1016/j.chemgeo.2013.10.002

Salome, K.R., Green, S.J., Beazley, M.J., Webb, S.M., Kostka, J.E., Taillefert, M., 2013. The role of anaerobic respiration in the immobilization of uranium through biomineralization of phosphate minerals. Geochim. Cosmochim. Acta 106, 344-363. doi:10.1016/j.gca.2012.12.037

Siebert, C., Nägler, T.F., von Blanckenburg, F., Kramers, J.D., 2003. Molybdenum isotope records as a potential new proxy for paleoceanography. Earth Planet. Sci. Lett. 211, 159171. doi:10.1016/S0012-821X(03)00189-4

Stewart, B.D., Girardot, C., Spycher, N., Sani, R.K., Peyton, B.M., 2012. Influence of chelating agents on biogenic uraninite reoxidation by Fe(III) (hydr)oxides. Environ. Sci. Technol. 47, 364-371. doi:10.1021/es303022p

Stirling, C.H., Andersen, M.B., Potter, E.K., Halliday, A.N., 2007. Low-temperature isotopic fractionation of uranium. Earth Planet. Sci. Lett. 264, 208-225. doi:10.1016/j.epsl.2007.09.019 
604

605

606

607

608

609

610

611

612

613

614

615

616

617

618

619

620

621

622

623

624

625

626

627

628

629 630 fractionation of 238U/235U. Geochim. Cosmochim. Acta 72, 345-359. 631 doi:10.1016/j.gca.2007.11.012

632 Yamada, M., Wang, Z.-L., Kato, Y., 2006. Precipitation of authigenic uranium in suboxic

Stirling, C.H., Andersen, M.B., Warthmann, R., Halliday, A.N., 2015. Isotope fractionation of $238 \mathrm{U}$ and $235 \mathrm{U}$ during biologically-mediated uranium reduction. Geochim. Cosmochim. Acta 163, 200-218. doi:10.1016/j.gca.2015.03.017

Stylo, M., Neubert, N., Wang, Y., Monga, N., Romaniello, S.J., Weyer, S., Bernier-Latmani, R., 2015. Uranium isotopes fingerprint biotic reduction. Proc. Natl. Acad. Sci. U. S. A. 112, 5619-24. doi:10.1073/pnas.1421841112

Sundby, B., Martinez, P., Gobeil, C., 2004. Comparative geochemistry of cadmium, rhenium, uranium, and molybdenum in continental margin sediments. Geochim. Cosmochim. Acta 68, 2485-2493. doi:10.1016/j.gca.2003.08.011

Tessier, E., Garnier, C., Mullot, J.-U., Lenoble, V., Arnaud, M., Raynaud, M., Mounier, S., 2011. Study of the spatial and historical distribution of sediment inorganic contamination in the Toulon bay (France). Mar. Pollut. Bull. 62, 2075-2086. doi:10.1016/j.marpolbul.2011.07.022

Tissot, F.L.H., Dauphas, N., 2015. Uranium isotopic compositions of the crust and ocean: Age corrections, $U$ budget and global extent of modern anoxia. Geochim. Cosmochim. Acta 167, 113-143. doi:10.1016/j.gca.2015.06.034

Tribovillard, N., Algeo, T.J., Lyons, T., Riboulleau, A., 2006. Trace metals as paleoredox and paleoproductivity proxies: An update. Chem. Geol. 232, 12-32. doi:10.1016/j.chemgeo.2006.02.012

Turekian, K.K., Wedepohl, K.H., 1961. Geological Society of America Bulletin Distribution of the Elements in Some Major Units of the Earth $\mathfrak{a}^{\mathrm{TM}}$ s Crust. Geol. Soc. Am. Bull. 72, 175-192. doi:10.1130/0016-7606(1961)72

Weber, K.A., Cameron Thrash, J., Ian Van Trump, J., Achenbach, L.A., Coates, J.D., 2011.

27 Environmental and taxonomic bacterial diversity of anaerobic uranium(IV) bio28 oxidation. Appl. Environ. Microbiol. 77, 4693-4696. doi:10.1128/AEM.02539-10

29 Weyer, S., Anbar, a. D., Gerdes, a., Gordon, G.W., Algeo, T.J., Boyle, E. a., 2008. Natural 
633 continental margin sediments from the Okinawa Trough. Estuar. Coast. Shelf Sci. 66, $634 \quad$ 570-579. doi:10.1016/j.ecss.2005.11.002

635 Zheng, Y., Anderson, R.F., Van Geen, A., Kuwabara, J., 2000. Authigenic molybdenum 636 formation in marine sediments: A link to pore water sulfide in the Santa Barbara Basin. 637 Geochim. Cosmochim. Acta 64, 4165-4178. doi:10.1016/S0016-7037(00)00495-6 638 


\section{TABLES}

Table 1: $U$ accumulation rate (integration of $U$ concentration with depth), percentage of authigenic $\mathrm{U}$ in the top surface sediments and $\mathrm{Ti} / \mathrm{Al}$ ratios at ten sediment cores in Toulon Bay.

\section{FIGURES}

Figure 1: Map of the study site with the main anthropogenic activities and locations of the 54 surface $(0-5 \mathrm{~cm})$ sediment samples (crosses) and 10 interface sediment cores (black circles). Uranium concentrations in surface sediments of the 54 stations are also shown. White labels show surface sediments where U isotope composition was analyzed.

Figure 2: Uranium profiles in sediment cores at ten stations.

Figure 3: (A) Vertical profile of $\mathrm{Ti} / \mathrm{Al}$ at ten stations, the vertical line and the grey zone indicates the average value and the range of $\mathrm{Ti} / \mathrm{Al}$ for the 54 stations in the whole bay. (B) A comparison of the vertical Ti/Al ratios and total U concentrations at station LAS2.

Figure 4: Authigenic U, Mo and V concentrations vs. Ti/Al ratios in sediments at stations LAS 0-1-2-3 (green circles) and MIS, 3B, 12, 15, 23, 52 and surface sediments (blue circles).

Figure 5: A multiple regression model of authigenic $U$ as a function of authigenic Mo and V. Four configurations are displayed and individual plots are shown in Figure S3. The $r^{2}$ values correspond to the relationship between observed vs. calculated authigenic U.

Figure 6: Vertical profiles of $U$ isotopic composition at eight stations, the vertical line and blue zone show the value and range of $\delta^{238} \mathrm{U}$ in seawater. The grey circles display the $\mathrm{U}$ isotopic profile in sediments at the US West Coast (Andersen et al., 2016).

Figure 7: (A) Total U versus U isotopic composition in Toulon Bay and also three types of sediments gathered from the literature (11 individual datasets are shown in Figure S6). (B) Uranium concentration versus $U$ isotopic composition in the authigenic fraction (semifilled symbols) and the bulk sediments (grey symbols) in Toulon Bay. The vertical line and blue zone display the $U$ isotopic composition of seawater, the vertical bold line shows the full $U$ fractionation factor from seawater $\left(\Delta^{238} U=1.2 \%\right.$ ). The two configurations: Oxic penetration zone and Partial $U$ porewater removal correspond to the half-U fractionation and full-U fractionation factors defined by Andersen et al. (2014)

Figure 8: Dissolved U and SRP profiles at seven stations. The grey zone at station 12 shows intra-site variation on triplicate cores while the dashed line indicates the range of seasonal variation for 10 cores. The grey zone in the $U$ plots for stations $3 B, 12$ and 52 corresponds to that in stations 15, LAS2-3 and 23 to better highlight the difference in axis scaling.

Figure 9: Relationship between dissolved and total $U$ at seven stations. 


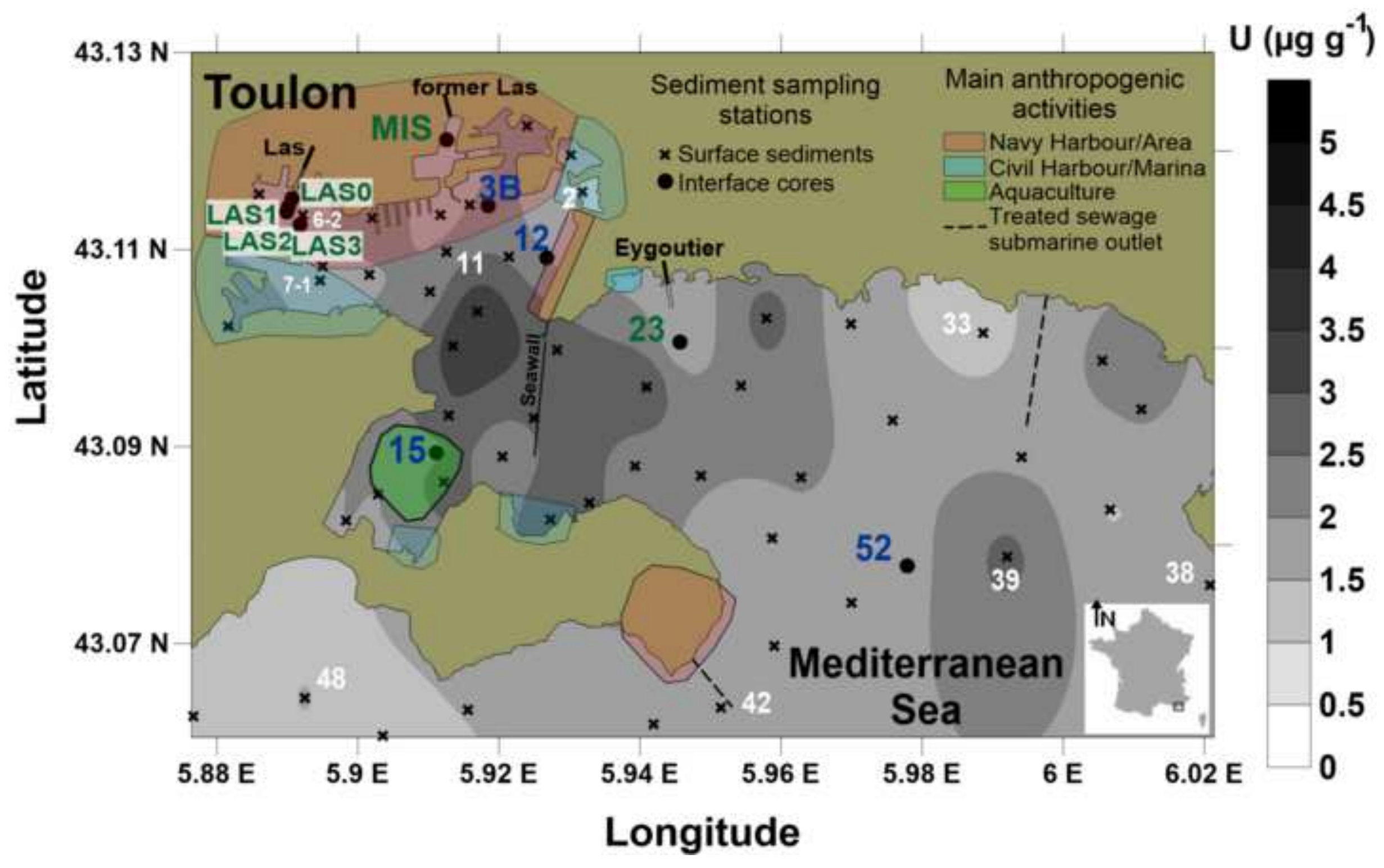




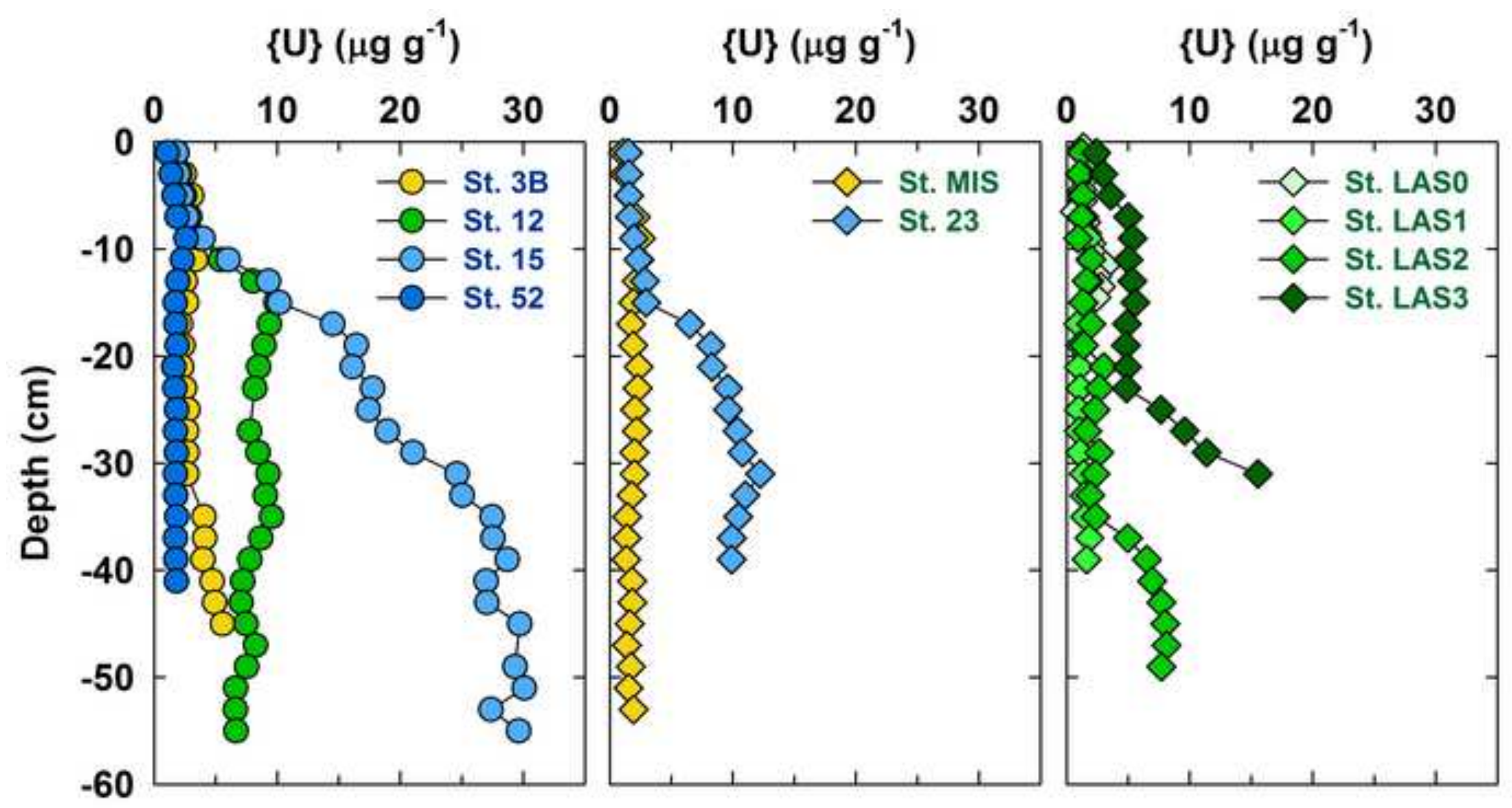


Ti/Al (x100)

Ti/Al (x100)

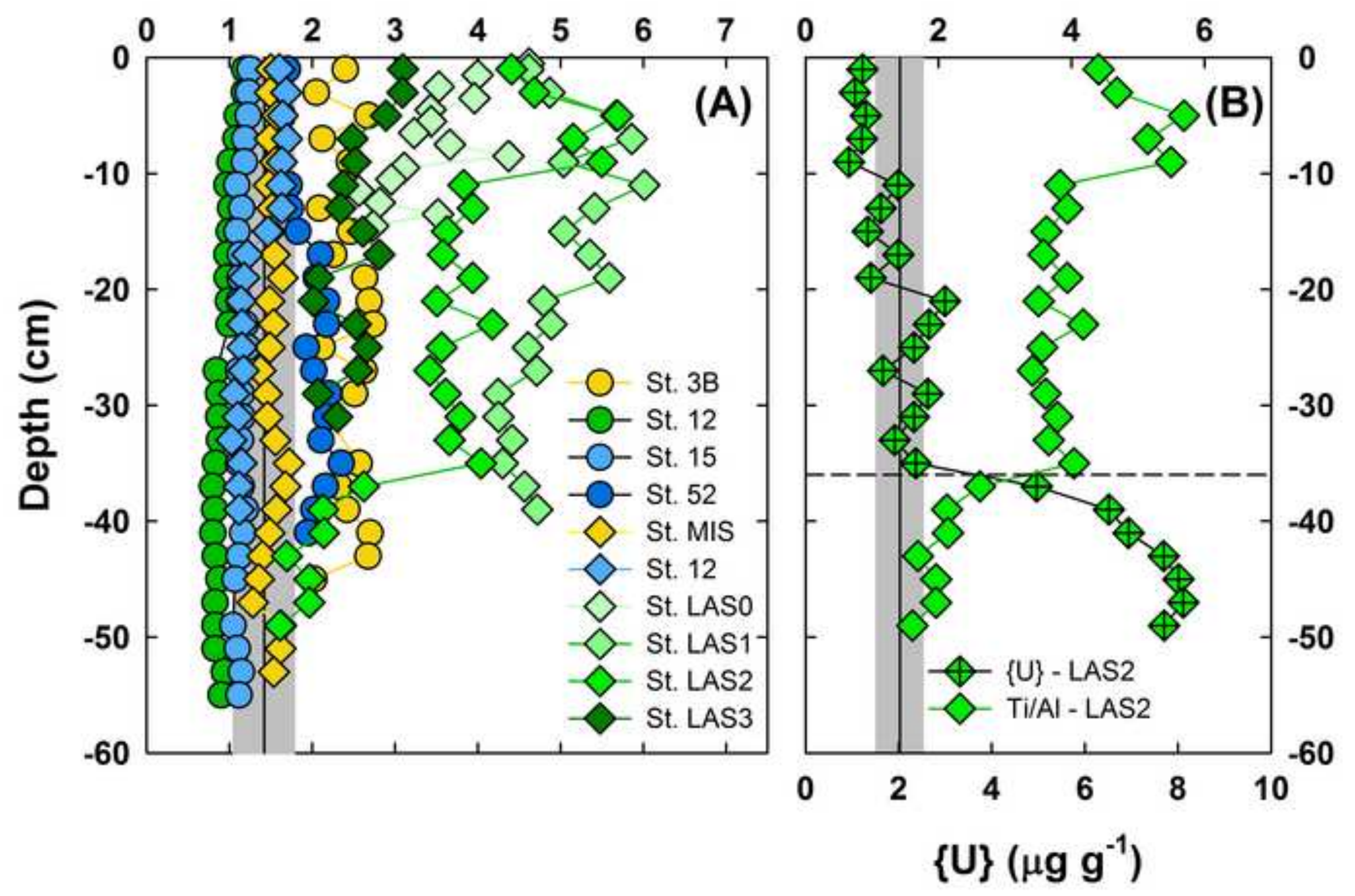


Figure 4

Click here to download high resolution image

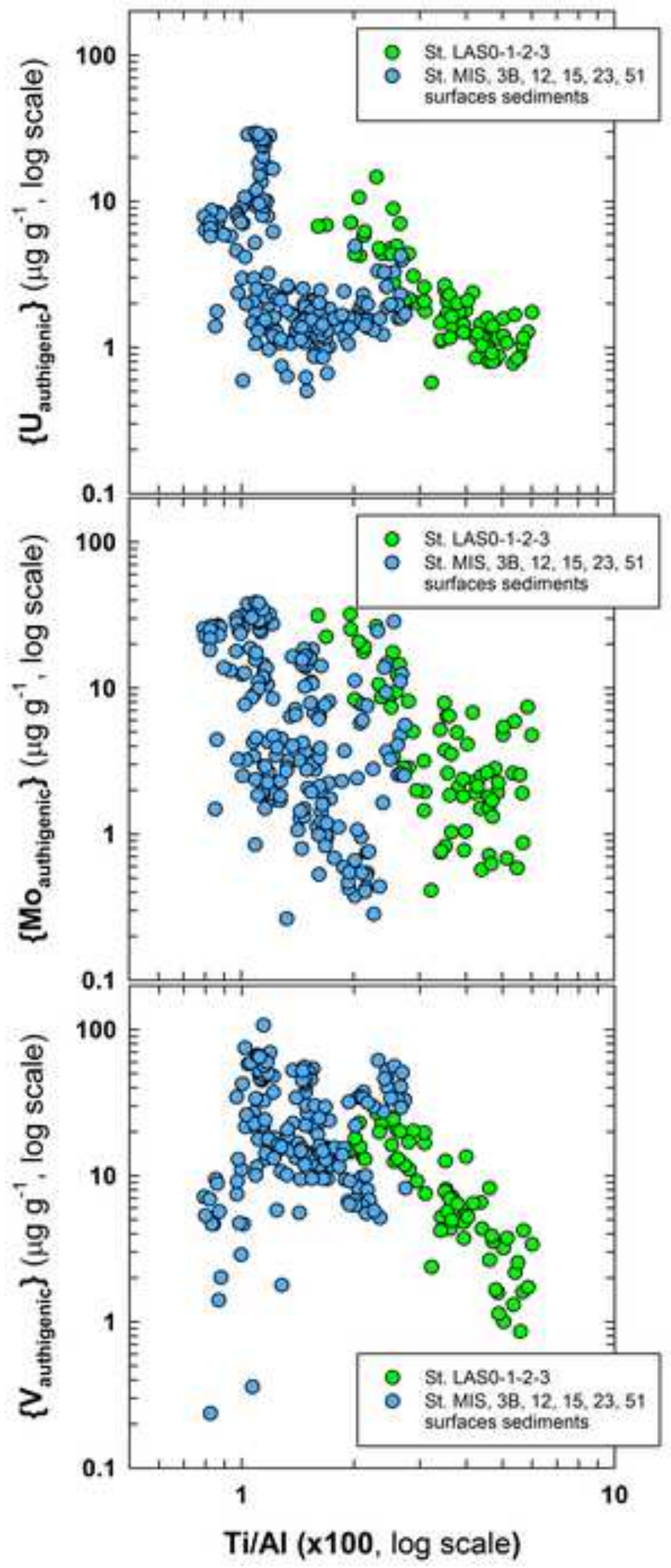



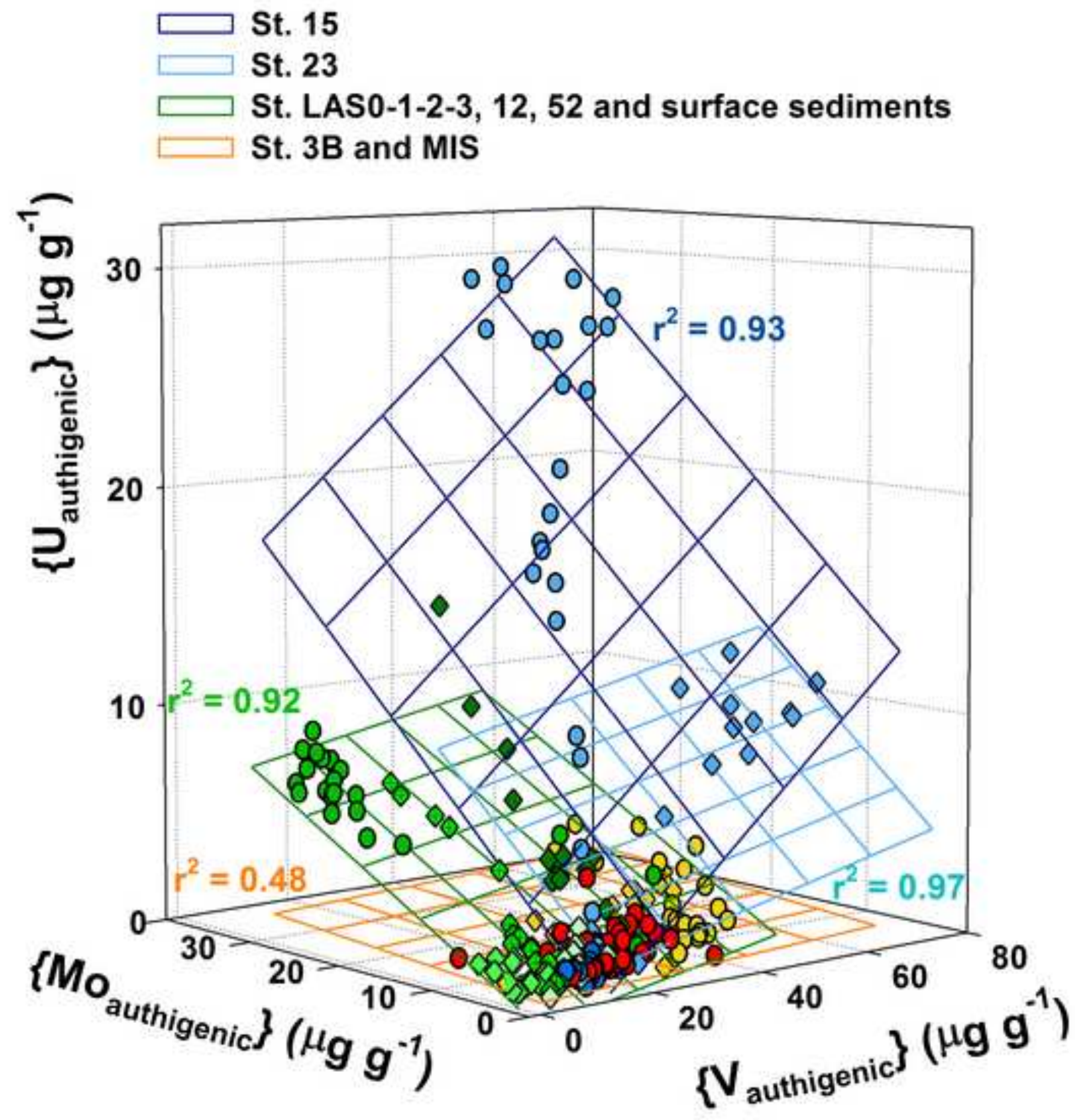


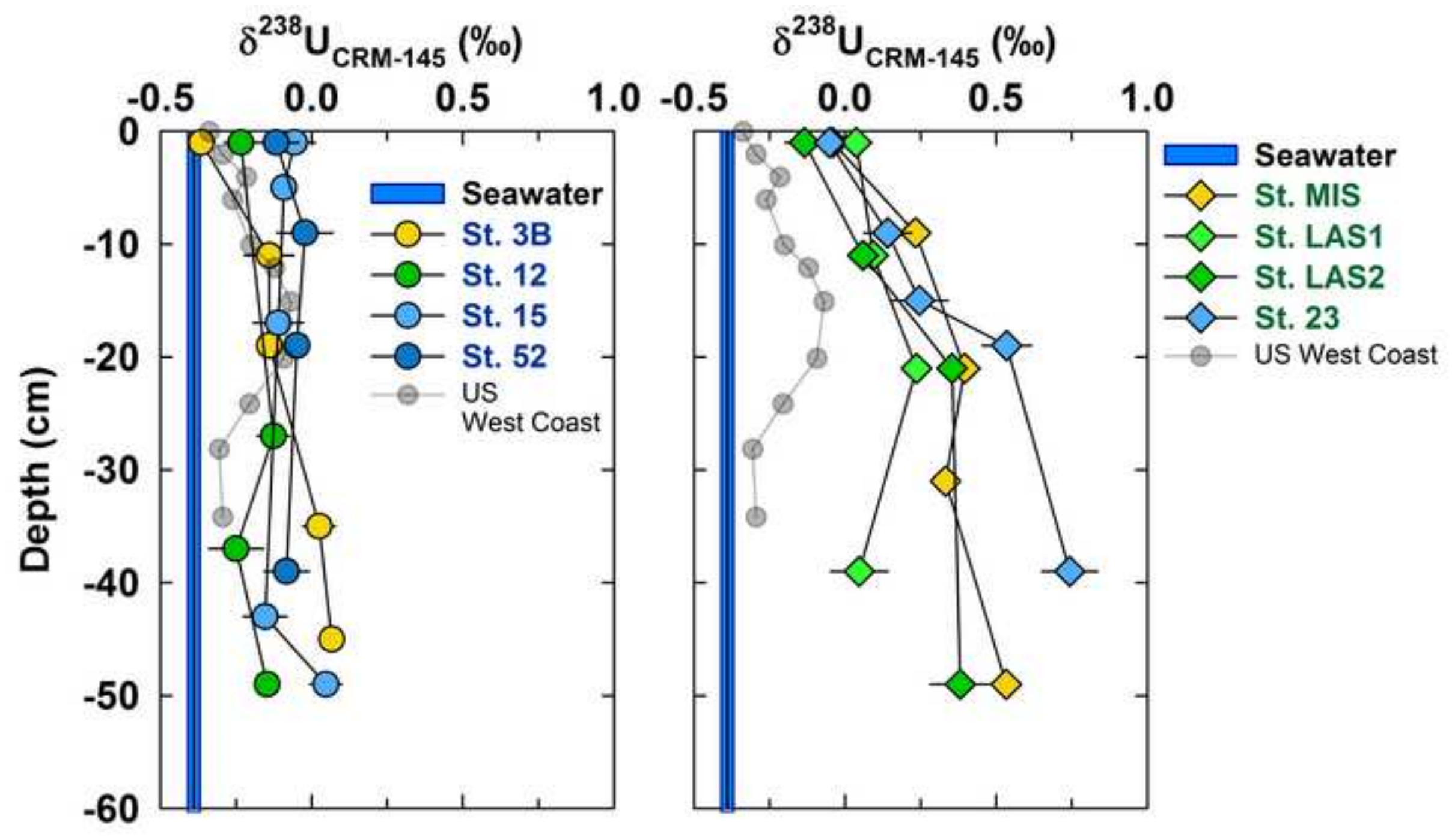


Click here to download high resolution image
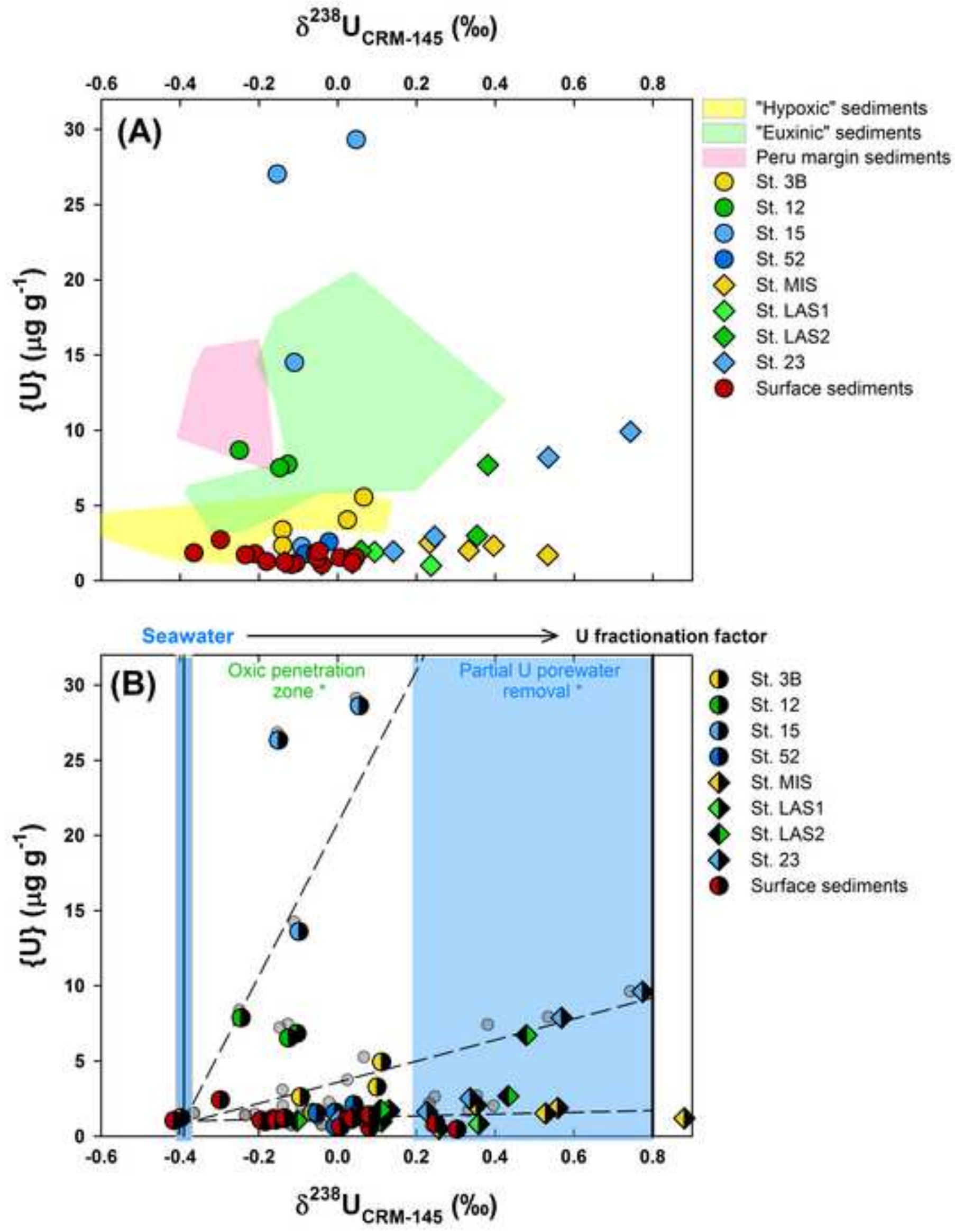

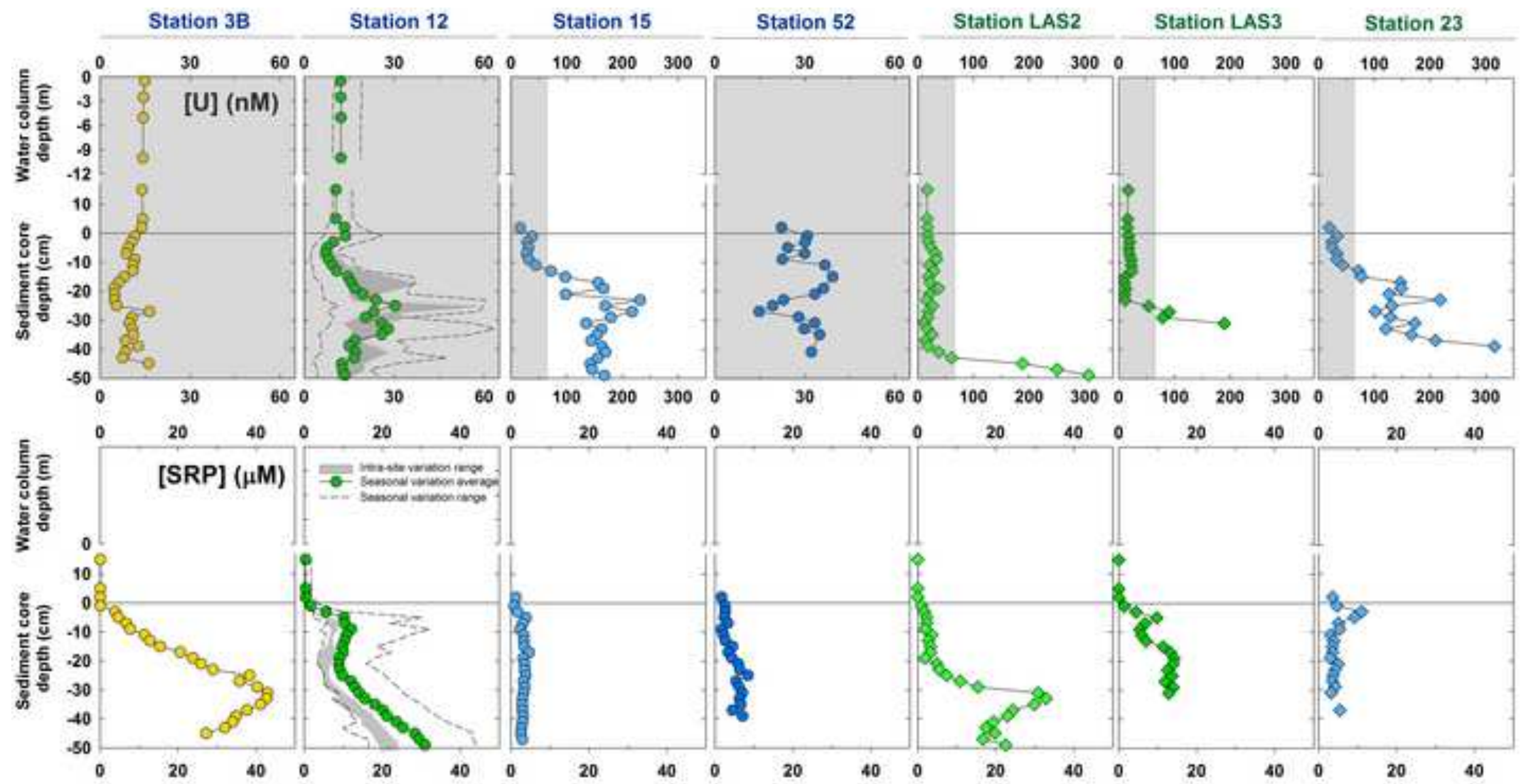


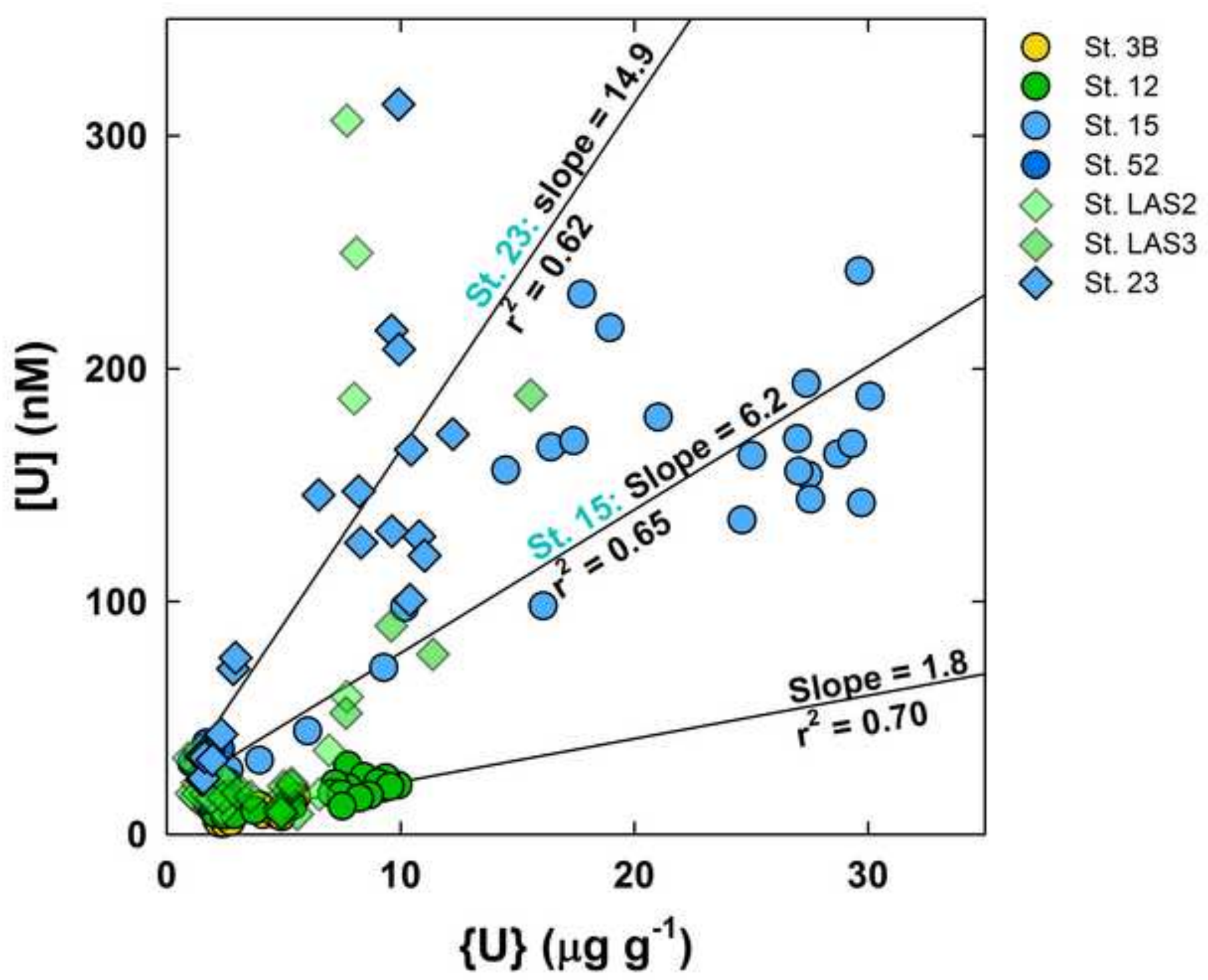


Table 1:

\begin{tabular}{|c|c|c|c|c|c|c|c|c|c|c|}
\hline Stations & 23 & LAS0 & LAS1 & LAS2 & LAS3 & MIS & 3B & 12 & 15 & 52 \\
\hline $\begin{array}{l}\text { Accumulation rate } \\
\left(\mathrm{g} \mathrm{v}^{-1} \mathrm{~cm}^{-1}\right) \\
(\text { first } 10 \mathrm{~cm})\end{array}$ & 0.03 & 0.10 & 0.06 & 0.0 & 0.4 & 0.19 & 0.17 & 0.24 & 0.14 & 0.13 \\
\hline $\begin{array}{l}\mathrm{r}^{2} \text { (linear increase in } \\
\{\mathrm{U}\} \text { with depth) }\end{array}$ & 0.99 & 0.2 & 0.68 & 0.2 & 0.96 & 0.95 & 0.86 & 0.96 & 0.96 & 1.00 \\
\hline Average & \multicolumn{6}{|c|}{$0.04 \pm 0.05$} & \multicolumn{4}{|c|}{$0.21 \pm 0.10$} \\
\hline $\begin{array}{c}\left\{\mathrm{U}_{\text {authigenic }}\right\}(\%) \\
\text { in } 0-2 \mathrm{~cm} \text { sediments }\end{array}$ & 81.3 & 83.3 & 82.0 & 84.0 & 86.1 & 46.6 & 66.0 & 56.3 & 62.9 & 62.2 \\
\hline Average & \multicolumn{5}{|c|}{$83.3 \pm 1.9$} & \multicolumn{5}{|c|}{$58.8 \pm 7.7$} \\
\hline $\begin{array}{l}\mathrm{Ti} / \mathrm{Al} \times 100 \\
( \pm \mathrm{sd})\end{array}$ & $\begin{array}{c}1.3 \\
(0.3)\end{array}$ & $\begin{array}{c}3.5 \\
(0.6)\end{array}$ & $\begin{array}{c}4.9 \\
(0.5)\end{array}$ & $\begin{array}{c}3.5 \\
(1.1)\end{array}$ & $\begin{array}{c}2.5 \\
(0.3)\end{array}$ & $\begin{array}{c}1.5 \\
(0.1)\end{array}$ & $\begin{array}{c}2.4 \\
(0.2)\end{array}$ & $\begin{array}{c}0.9 \\
(0.1)\end{array}$ & $\begin{array}{l}1.1 \\
(0.1)\end{array}$ & $\begin{array}{l}1.9 \\
(0.2)\end{array}$ \\
\hline
\end{tabular}


